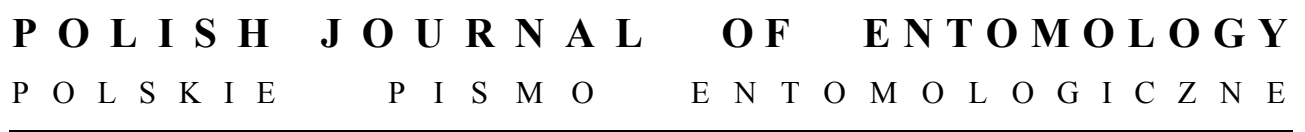

VOL. 80: $123-128$

Gdynia

31 March 2011

DOI: $10.2478 / \mathrm{v} 10200-011-0009-0$

\title{
Agriella gavrylenkoi, a new species of fleshfly from Ukraine (Diptera: Sarcophagidae: Sarcophaginae)
}

\author{
YURIY VERVES*, KRZYSZTOF SZPILA** \\ *Institute of Plant Protection, Laboratory of Entomology, Vasylkivs'ka 33, \\ Kyiv 03022, Ukraine, e-mail: fly_@voliacable.com; \\ **Nicolaus Copernicus University, Institute of Ecology and Environmental Protection, \\ Department of Animal Ecology, Gagarina 9, 87-100 Toruń, Poland, \\ e-mail: szpila@umk.pl
}

\begin{abstract}
Agriella gavrylenkoi sp. n. is described and illustrated. One male was collected on the loamy coasts of the Sivash saline lagoon in southern Ukraine. Agriella gavrylenkoi is well differentiated from closely related species by the weakly developed lateral spots on the abdominal tergites and the very narrow juxta of the phallus. Blaesoxipha tunisia PAPE, 1994 is placed in the genus Agriella: A. tunisia, comb. n.
\end{abstract}

KEY WORDS: Sarcophagidae, Sarcophaginae, Agriella, new species, Ukraine, Palaearctic Region.

\section{INTRODUCTION}

The genus Agriella Villeneuve, 1911 (type species: Agriella pandellei Villeneuve, 1911, by monotypy) belongs to the tribe Protodexiini and is very similar to Blaesoxipha LOEW, 1861 but is distinctly differentiated by the closed or petiolate cell $r_{4+5}$ of the wing and by the structural peculiarities of the distiphallus (VILLENEUVE, 1911; SALEM 1938; VERVES 1985, 1986; LEHRER 2003). We propose to place Blaesoxipha tunisia PAPE, 1994 in the genus Agriella: A. tunisia, comb. n. As a result, seventeen known species of this genus are distributed in the arid zones of the Palaearctic region. They are reported from Ukraine for the first time. The larvae are known to be internal parasites of tenebrionid adult beetles (Anatolica abbreviata, A. angustata, Tentyria nomas): female flies inject the first 
stage larvae into the oral opening of the host (KNOR 1970, KOLOMYIETZ 1971, CHARYKULIEV \& NEPESOVA 1972).

One specimen of Agriella was collected by hand net on the loamy coasts of the Sivash (Fig. 1), a saline lagoon of southern Ukraine along the northeastern coast of Crimea. Detailed studies have proven it to be a new species. It is named in honour of the famous Ukrainian protector of the environment, director of the "Askania Nova" Biosphere Reserve Dr. Victor S. Gavrylenko.

The terminology of the description follows MERZ \& HAENNI (2000) with a few modifications proposed by Verves (2000), VerVEs \& KHROKALO (2006), SZPILA \& PAPE (2007). The photographs were taken with a Nikon 8400 digital camera mounted on a Nikon SMZ1500 stereomicroscope.

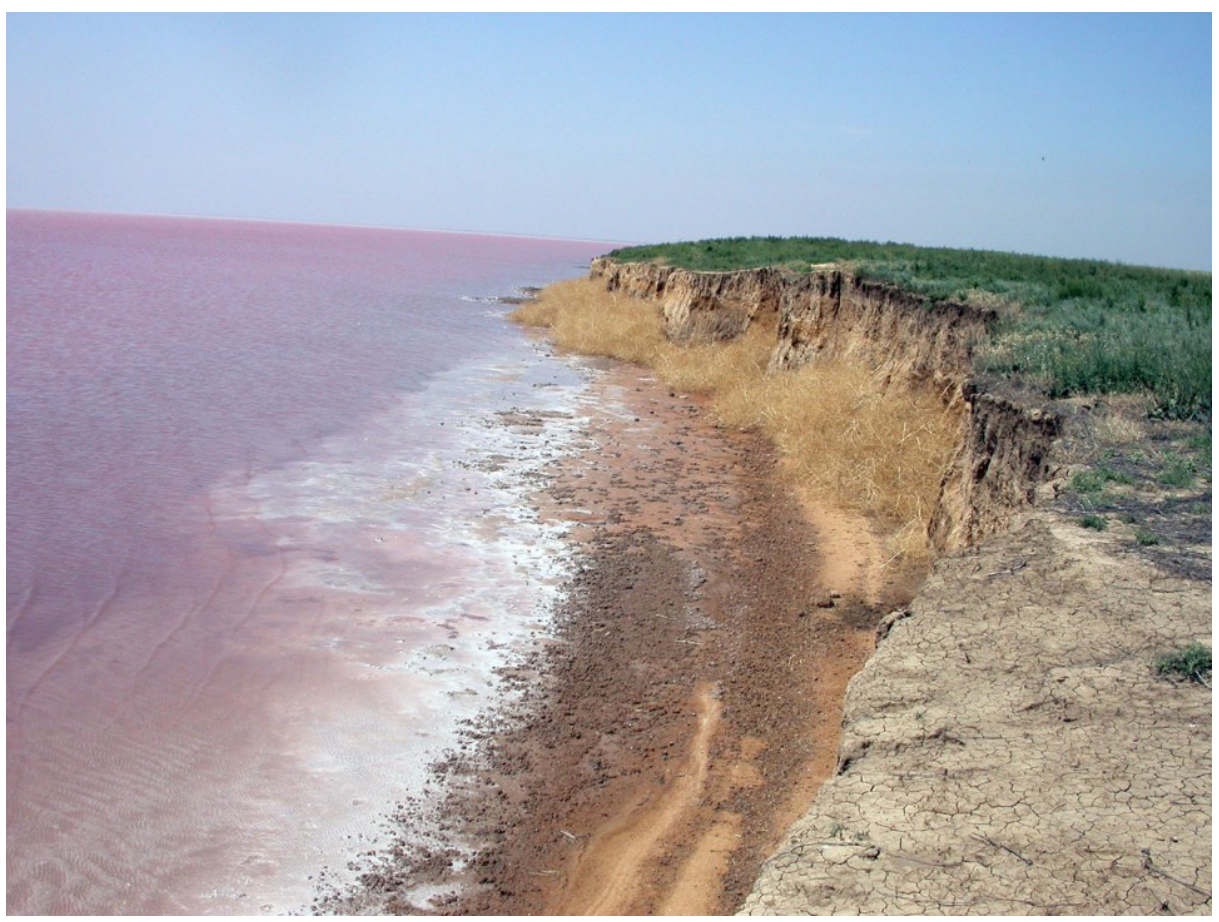

Fig. 1. The loamy Sivash coast near the village of Ivanivka.

\section{Acknowledgements}

We are grateful to the Director of the Institute of Plant Protection (Kyiv) Prof. Vitaliy Fedorenko, to the Director of the "Askania Nova" Biosphere Reserve Dr. Victor Gavrylenko, and to Dr. Oleksandr Senchylo (Botany Department of Kyiv Taras 
Shevchenko National University) for their kind assistance in the organization of our scientific expedition and investigations.

This work was financially supported by the Polish Ministry of Science and Higher Education (grant no. N N303 470838).

\section{RESULTS}

\section{Agriella gavrylenkoi sp. $\mathbf{n}$.}

(Figs 2-4)

\section{Diagnosis}

This species is similar to Agriella setosa SALEM, 1938 in that it has a black flagellomere, one row of parafacial setae, a rectangulate, dorsally curved apical part of the cercus and short ventral processes on the distiphallus, but is well differentiated by the weakly developed lateral spots on the abdominal tergites and the very narrow juxta.

\section{Description}

Body length: $6.0 \mathrm{~mm}$.

Head: frons at level of posterior ocelli equal to 0.21 , in the narrowest part 0.17 , at the antennal base 0.36 of the head width. Fronto-orbital plates and parafacials densely dusted greyish white; frontal vitta in fore part almost black, its hind part dusted grey, in the narrowest part of the frons 1.8-1.9 $\mathrm{x}$ as wide as one of the fronto-orbital plates, but slightly constricted in centre; anterior to posterior width ratio 1.0:1.2. Flagellomere $1.7 \mathrm{x}$ as long as pedicel, arista long pubescent, thickened in basal $0.2-0.3$, antenna completely greyishblack, apex of pedicel and base of flagellomere reddish; palpus slightly widened at apex, brownish black. Proboscis about 4 times as long as width. Parafacial at level of antennal base is $0.20 \mathrm{x}$, gena $0.22 \mathrm{x}$ of eye height. One regular row of postocular setae present; outer vertical bristles about $0.5 \mathrm{x}$ as long as inner vertical bristles; ocellar bristles strong and long, directed latero-anteriorly; 2 pairs of fine postocellar bristles; orbital bristles strong, 1+0, parafrons practically bare; 9 pairs of medium-length frontal bristles. Parafacials with one vertical row of black fine setae. Face, lunula, genal groove and facial ridge dusted pale silver-grey. Vibrissae well developed; subvibrissal setae black, of medium length and relatively strong. Genae dusted grey, covered with black setae, postgenae and occiput also dusted grey, intermixed with short black setae in the upper part and medium-length golden white hairs in lower part.

Thorax: black, densely dusted light-grey, covered with black hairs; mesonotum with one broad median and two lateral black stripes, median stripe subdivided into three narrower ones near transverse suture. Scutellum wholly dusted pale grey. Lateral parts of thorax 
densely dusted grey. acr 3-4 +3-4, only presutural pair strong; $d c 2+3$, strong; ial $1+3$; prs 1; spal 3-4; $h$ 3; ph 2-3; proanepisternum bare; $n p l ~ 2$, in addition to those bristles, notopleural area covered by several short erect hairs; anepisternum covered with mediumlength dense hairs and a row of 7-8 further long, strong posterior bristles; katepisternum with long anterior and posterior bristles $(1+1)$, one more short bristle placed behind the fore bristle. Scutellum with long and strong paired parallel preapical and basal paired bristles, apical ones fine and crossed; one pair of discals well developed, very much longer than discal hairs. Fore and hind spiracles brownish black.

Wing: hyaline, veins blackish brown; basicosta and tegula whitish yellow. Costal spine well developed, of medium-length; cell $r_{4+5}$ closed; vein $R_{1}$ bare, node of vein $R_{4+5}$ with 3-4 black setae above and 1-2 below; vein dm-cu distinctly curved; $M$ right-angled, with very short appendix; ratio of $3^{\text {rd }}$ and $5^{\text {th }}$ costal sections $=1: 0.91$; ratio of lengths of $2^{\text {nd }}$ and $3^{\text {rd }} \mathrm{M}-$ sections $=1: 0.36$. Thoracic squama white, bare on upper surface. Haltere light brown except for whitish knob.

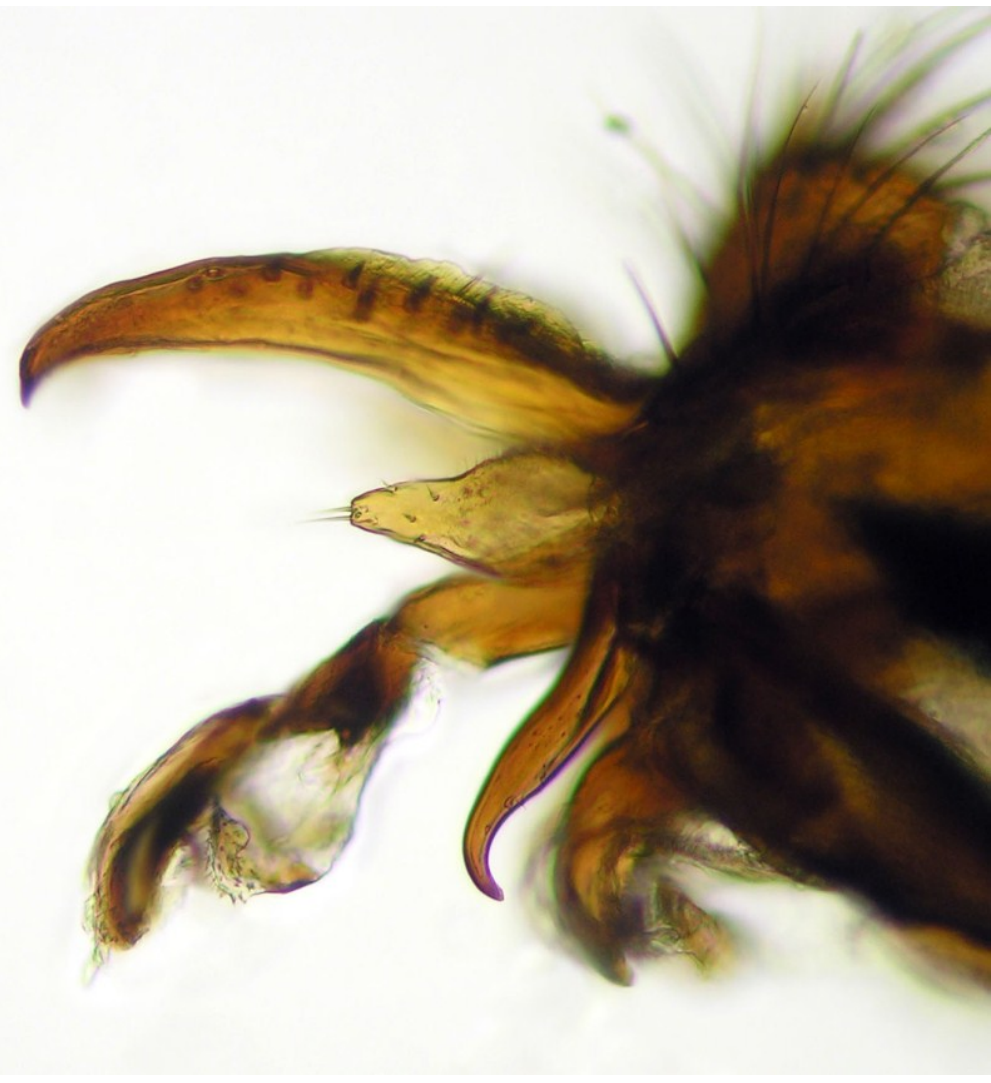

Fig. 2. Male genitalia of Agriella gavrylenkoi sp. n. - lateral aspect. 


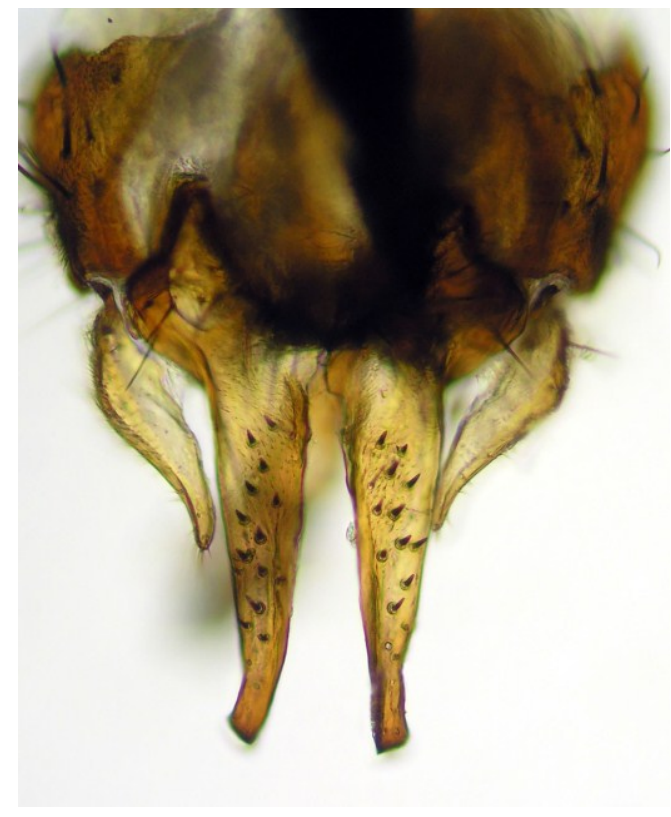

b

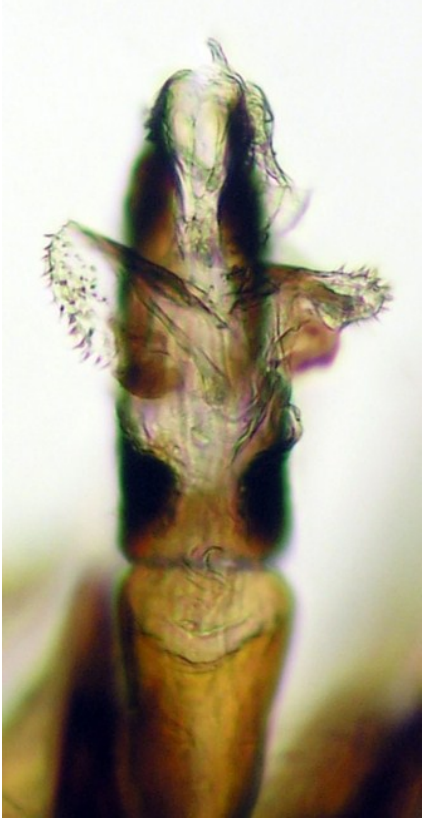

Fig. 3. Male genitalia of Agriella gavrylenkoi sp. n., a. cerci and surstyli, dorsal aspect, b. phallus, ventral aspect.

Legs: Claws elongate, slightly curved, as long as $5^{\text {th }}$ tarsomere; fore tibia with $2 \mathrm{ad}$ on basal half; mid tibia with 2-3 ad.

Abdomen: narrow, elongate-conical, black, densely dusted light grey, with black narrow longitudinal stripe on all tergites and small blurred lateral spots in fore 0.1 of $3^{\text {rd }}-4^{\text {th }}$ tergites; $2^{\text {rd }}$ and $3^{\text {rd }}$ tergites without mediomarginal bristles; $4^{\text {th }}$ and $5^{\text {th }}$ tergites with rows of marginals. Each of $2^{\text {nd }}-4^{\text {th }}$ sternites covered by long erect hairs.

Genitalia: small, not prominent, $6^{\text {th }}$ tergite, $7+8^{\text {th }}$ syntergosternite and epandrium reddish brown, distinctly dusted grey; $7+8^{\text {th }}$ syntergosternite with a row of mediomarginals. Cercus in profile hook-like, its apical part rectangulate curved; ventral processes of distiphallus short, juxta narrow (Figs 2-3).

Female. Unknown.

\section{Type material}

Holotype: male, Ukraine, Kherson region, $50 \mathrm{~km} \mathrm{~S}$ of Askania Nova, coast of Sivash, close to the village of Ivanivka $\left(46^{\circ} 13^{\prime} \mathrm{N}, 33^{\circ} 55^{\prime} \mathrm{E}\right), 24$ VII 2008, coll. Yu. Verves \& K. Szpila. The holotype is deposited in the Natural History Museum of Denmark, Zoological Museum. 


\section{REFERENCES}

Charykuliev D.M., NePesova M.G. 1972. On parasitism of sarcophagid flies in darkling beetles. Izvestiya Akademii Nauk Turkmenskoy SSR. Seriya Biologicheskih Nauk 5: 71-73. [In Russian].

KNOR I.B. 1970. The parasites of tenebrionid beetles (Coleoptera, Tenebrionidae) from Kulunda of Altay Kray. Entomologicheskoe Obozrenie 49: 736-748. [In Russian with English summary].

KolomyiEtz N.G. 1971. A new species of the genus Blaesoxipha Lw. (Diptera, Sarcophagidae) from Siberia parasiting on darkling beetles (Coleoptera, Tenebrionidae). New and little known species of Siberian fauna 5: 115-120. [In Russian with English summary].

LeHRER A.Z. 2003. Sarcophaginae de l'Afrique (Insecta, Diptera, Sarcophagidae). Entomologica, Bari 37: 5-528.

Merz B., HAENNI J.P. 2000. Morphology and terminology of adult Diptera (other than terminalia). [In:] L. PAPP, B. DARVAS (eds.). Contributions to a Manual of Palaearctic Diptera (with special reference to flies of economic importance). Science Herald Press, Budapest, pp. 21-51.

Salem H.H. 1938. The species of the genus Agriella Villeneuve, 1911 (Diptera, Tachinidae, Sarcophaginae). Egyptian University, Faculty of Medicine Publication 14: 1-16.

SZPILA K., PAPE T. 2007. Rediscovery, redescription and reclassification of Beludzhia phylloteliptera (Diptera: Sarcophagidae: Miltogramminae). European Journal of Entomology 104: 119-137.

Verves Yu.G. 1985. 64h. Sarcophaginae. [In:] E. LindNER (ed.). Die Fliegen der palaearktischen Region 11 (Lieferung 330). Stuttgart, pp. 297-400.

Verves Yu.G. 1986. Family Sarcophagidae. [In:] A. Soos, L. PAPP (eds). Catalogue of Palaearctic Diptera. 12. Calliphoridae - Sarcophagidae. Academy Press, Budapest, pp. 58-193.

VERVES Yu.G. 2000. Rational nomenclature of the male genitalia of Sarcophagidae (Diptera). An International Journal of Dipterological Research, Saint-Petersburg 11: 117-127.

Verves Yu.G., Khrokalo L.A. 2006. 123. Fam. Sarcophagidae - sarcophagids. [In:] A.S. Leley (ed.). Key to the insects of Russian Far East. Vol. 6. Diptera and Siphonaptera. Pt 4. Dal'nauka; Vladivostok, pp. 64-178. [In Russian].

Villeneuve J. 1911. Dipterologische Sammelreise nach Korsika (Dipt.). (Schluss). Tachinidae. Deutsche Entomologische Zeitschrift 56: 117-130.

Received: December 17, 2010

Accepted: January 17, 2011 